\title{
Perspective of Emerging Integrating Technology (ICT) in Learning and Teaching
}

\author{
Boa Reena Tok and Marpe Sora
}

\begin{abstract}
The successful integration of information and communication technologies (ICT) into educational settings has become key factor for all educators. The information revolution is linked with the knowledge economy and Globalization. The knowledge economy is dependent on people's ability to adapt new situations, update their knowledge, know where to find the knowledge (networking), and to apply it to new situations. Globalization is another factor emerging within the knowledge economy, which has been led by an increasing awareness of interdependence in world affairs, and partly attributed to advances in communications and information technology. ICTs refer to a set of diverse technological tools and resources to create, disseminate, store, evaluate, circulate and manage information. With the advent of ICT we have acquired new dimensions such as that of ICT access, ICT capacity-building, ICT facilities, ICT employability and these technologies can be used to facilitate the development of online communities in which all participants collaborate to discuss, reflect on deepen their understanding of learning. The new communication technology especially Internet and mobile technology, leads to publicize the information. The objective of this paper is how ICT based teaching in classroom activities can produce significant changes both in the nature of the knowledge imparting and in the nature of the processes involved in acquiring it. The purpose is to give a brief idea about this new trend in higher education to boost towards utilizing information and communication technologies (ICT) to the fullest extent.
\end{abstract}

Index Terms_-Podcasting, blogs, wiki, online learning.

\section{INTRODUCTION}

Technology based learning and teaching in Higher Education: Institutions of higher education have increasingly embraced online education, and the number of students enrolled in distance programs is rapidly rising in colleges and universities worldwide. In response to these changes in enrolment demands, many country, institutions, and organizations have been working on strategic plans to implement online education. Following Fig. 1 (a), (b), (c), (d), (e), (f) show the power of relationships between tutor(T) and student(S) in online groups[1]. In which Tutor provides feedback and grades to validate the students work.

Manuscript received September 12, 2012; revised January 20, 2013.

Boa Reena Tok and Marpe Sora are with Rajiv Gandhi University, India (e-mail: wyliang@cc.ncue.edu.tw).

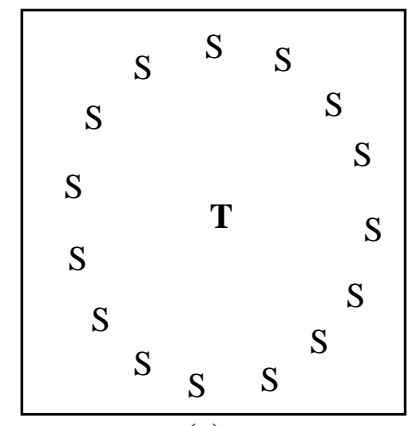

(a)

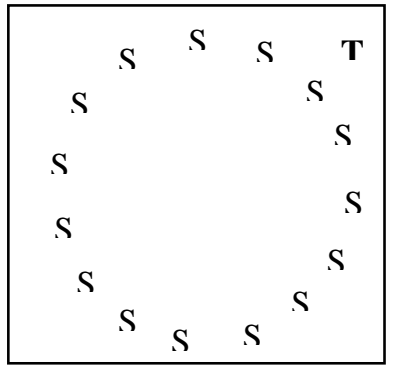

(c)

\begin{tabular}{|cc|}
\hline S & \\
S S & T \\
S S & \\
S & S S S S S \\
S S S & S S S \\
\hline
\end{tabular}

(e)

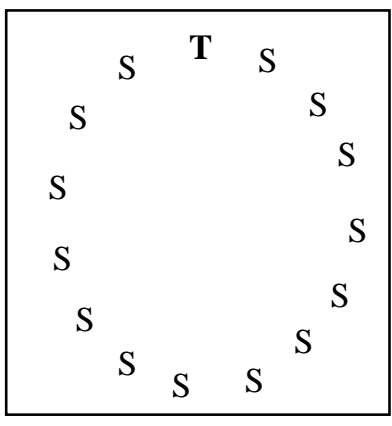

(b)

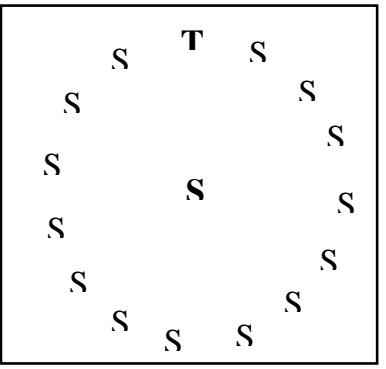

(d)

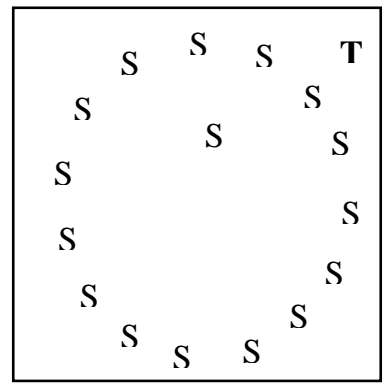

(f)
Fig. 1 (a), (b), (c), (d), (e), (f) Online cluster of relationship between teacher(T) and student(S).

Today's Higher education has supported by dozens of e-learning technologies (for instance, electronic books, simulations, text messaging, podcasting, wikis, and blogs). Technology has played and continues to play an important role in the development and expansion of online education. Accordingly, many universities have reported an increase in the use of online tools. The literature relate to effective practices in the use of emerging technologies for online education, empirical evidence to support or refute the effectiveness of such technologies, or, perhaps more importantly, guidance on how to use such tools effectively based on empirical evidence, is lacking[2].

\section{BACKGROUND}

The question of how Information and Communication 
Technology (ICT) impacts on learning and attainment has been posed frequently in recent years and has been investigated in large scale and small scale studies. A number of potentially helpful features characteristic of ICT have been identified. There is substantial evidence concerning ICT's ability to motivate learners to engage in cognitive and, perhaps more importantly, metacognitive activity. Many teachers are now incorporating ICT into their everyday practice, particularly in well-resourced schools with data projectors and interactive whiteboards. The speed and extent of this development can vary between teachers depending on their degree of confidence and competence with these digital technologies. The speed and repetition features of ICT were exploited when learners were able to see a rapid succession of cases of a particular phenomenon, which could help with inductive concept generation [3]. The present scenario of education has manifold changes due to various aspects of our civilization such as population explosion, advancement in science and technology, knowledge expansion, rapid industrialization, urbanization, mobilization as well as IT revolution, the present society become highly dynamic. The world today is witnessing a new kind of information revolution-ushered by technology. At present majority of devices are based on Digital Technology. The computers were never developed for improving quality of teaching learning process. But researchers started using Computers for teaching purpose. It gave birth to Computer Assisted Instruction (CAI), Computer Managed Instruction (CMI), Computer Based Instruction (CBI), etc. People started developing CAI for teaching different subjects at School as well as Higher Education level. The developed CAIs were compared with the Lecture Method / Traditional Method and found that the developed CAIs were significantly superior to Lecture Method / Traditional Method in teaching different subjects. In earlier days IT was limited only to the textual mode of transmission of information with ease and fast. But due speed accessing networking of computers the information not only in textual form but in audio, video or any other media is also to be transmitted to the users. Thus, the ICT $=$ IT + Other media. It has opened new avenues, like, Online learning, e-learning, Virtual University, e-coaching, e-education, e-journal, e-book etc. Third Generation Mobiles such as iPhone, smart phone etc. are also part of ICT. Mobile is being used in imparting information fast and cost effective. It provides e-mail facility also. One can access it anywhere. It will be cost effective. The ICT brings more rich material in the classrooms and libraries for the teachers and students. It has provided opportunity for the learner to use maximum senses to get the information. It has broken the monotony and provided variety in the teaching - learning situation. The ICT being latest, it can be used both at school and higher education levels in the following areas

- Teaching

- Diagnostic Testing

- Remedial Teaching

- Evaluation

- Psychological Testing

- Development of Virtual Laboratory

- Online Tutoring

- Development of Reasoning \& Thinking
- Instructional Material Development

The objectives of teaching are multi-dimensional in nature, so for the achievement multiple methods should be used in an integrated fashion. At present ICT may be of a number of uses. It is a well known fact that not a single teacher is capable of giving up to date and complete information in his own subject. The ICT can fill this gap because it can provide access to different sources of information. It will provide correct information as comprehensive as possible in different formats with different examples. ICT provides online interaction facility. Students and teachers can exchange their ideas and views, and get clarification on any topic from different experts, practitioners, etc. It helps learners to broaden the information base. ICT provides variety in the presentation of content which helps learners in concentration, better understanding, and long retention of information which is not possible otherwise. The learners can get opportunity to work on any live project with learners and experts from other countries. The super highway and cyber space also help in qualitative improvement of Teaching Learning Process. ICT provides flexibility to a learner which is denied by the traditional process and method. Flexibility is a must for mastery learning and quality learning. On INTERNET many websites are available freely which may be utilized by teachers and students for understanding different concepts, improving vocabulary, developing Reasoning \& Thinking, etc. ICT can help in preparing students for SAT, GRE, TOEFL, etc [4].

\section{Methodology}

This study is based on a survey of individuals the age between 25 to 45 years which is believed to have relevant experience with and insights into the factors affecting the present and future state of emerging technology in the education. An online and offline survey was conducted, in offline questionnaire was given university campus official staff such as Administrator, Research Scholar, Assistant Professor, Associate Professor and professor. In the University around 50 participants share their views as it is given in the Table I. Online survey based on social network has also responded at 200 participants share their view.

Most of the participants feel that the impact of communication technology strengthening the relevance of education in a teaching learning situation or classroom situation and helping to built teaching and learning into an engaging active process connected to the real life. The learners feel that it easy to download most recent edition e-books, research paper online. The learner enjoys purchasing books, educational software through online-shopping such as flipkart.com. Some student reported the use of blogs the student's collaboration and reflection. Through Podcasting the educator able to find audio, video, pdf and epub files. Wiki allows the educators to express their views and share knowledge. Scholars do realize that new communication technologies should be used to enhance skills of learning [5].

\section{Pedagogy And TeChnOlogy}

Technology design and use should be progressively 
considered in relation to the whole teaching and learning activity and not merely to the development of specific abilities and/or the accomplishment of particular tasks.[6]. Online learning environments provide a unique opportunity for the academic to establish a community of learners, where the academic manages a process rather than providing all input and expertise [7]. Sharing of information online it will be access to all learners. Whereas one-on-one assistance and advice while learning in traditional based classroom.

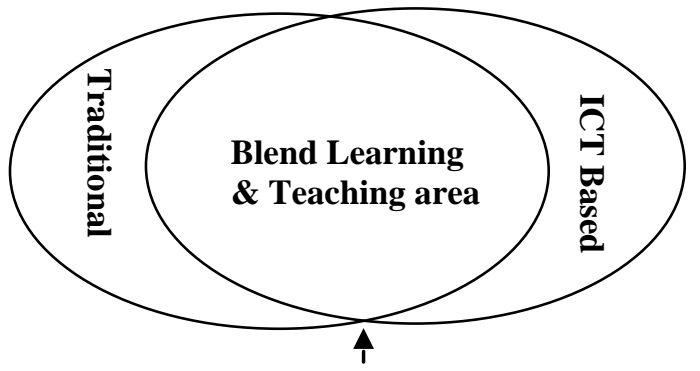

Areas in which traditional versus ICT based Teaching and learning systems. Where two together readily outperform either alone (greater domain).

Fig. 2. Comparisons of traditional, ICT based and blend learning and teaching.

TABLE I: BLEND QUALITY OF ICT BASED VERSUS TRADITIONAL EDUCATION

\begin{tabular}{|l|l|l|}
\hline Response Option & $\begin{array}{l}\text { Number of } \\
\text { respondent }\end{array}$ & $\begin{array}{l}\text { Respond } \\
\text { rate(\%) }\end{array}$ \\
\hline $\begin{array}{l}\text { 1. Do you adequate access to network } \\
\text { computers }\end{array}$ & 45 & $90 \%$ \\
\hline $\begin{array}{l}\text { 2. Do you add your students as a friend } \\
\text { in social network }\end{array}$ & 37 & $74 \%$ \\
\hline $\begin{array}{l}\text { 3. Are your students well equipped to } \\
\text { work in electronic environment }\end{array}$ & 25 & $50 \%$ \\
\hline $\begin{array}{l}\text { 4. Do you have General computing skill, } \\
\text { familiarity with e-mail and the web }\end{array}$ & 47 & $94 \%$ \\
\hline $\begin{array}{l}\text { 5. Are you aware of the procedures for } \\
\text { putting resources on to your institution's } \\
\text { network or web server }\end{array}$ & 17 & $34 \%$ \\
\hline 6. Do you have Technical support & 33 & $66 \%$ \\
\hline $\begin{array}{l}\text { 7. What benefits are you hoping to gain } \\
\text { from net? What will be the benefits for } \\
\text { your students }\end{array}$ & 42 & $64 \%$ \\
\hline $\begin{array}{l}\text { 8. What disadvantages can you foresee } \\
\text { and how it might be avoided or managed }\end{array}$ & 28 & $\mathbf{1 0 0 \%}$ \\
\hline $\begin{array}{l}\text { 9. How do you think your students will } \\
\text { react to this use of technology }\end{array}$ & 34 & $66 \%$ \\
\hline $\begin{array}{l}\text { 10. Expected Quality of Online compare } \\
\text { to Traditional Education system }\end{array}$ & 33 & $56 \%$ \\
\hline Average responded & $\mathbf{5 0}$ & \\
\hline Average non responses & & \\
\hline Total & $28 \%$ \\
\hline
\end{tabular}

Our formal education systems are designed to help students move up the expertise scale in the various disciplines covered in the curriculum. Here is an example of such a scale for teacher and student knowledge enhancement skills in ICT in based education. Naïve user and Intermediate user they use the digital resources to enhance learning process. The concepts of higher-order skills and lower-order skills is closely related to the Expertise Scale. Wider access of educational opportunities offered by ICT and promotes new competencies required for improving teaching and learning. Change of organization in the classroom appears to be caused by the combined effect of the digital media being used in the teaching approach being applied that of placing emphasis on the learning processes.

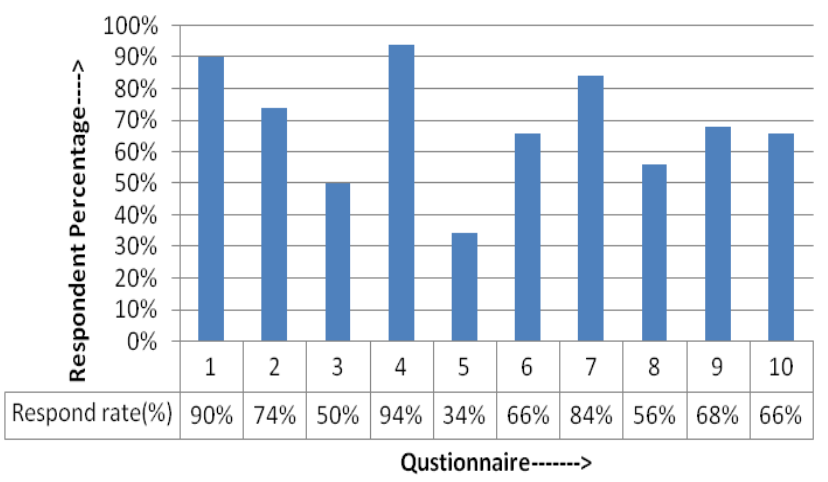

Fig. 3. Respond rate.

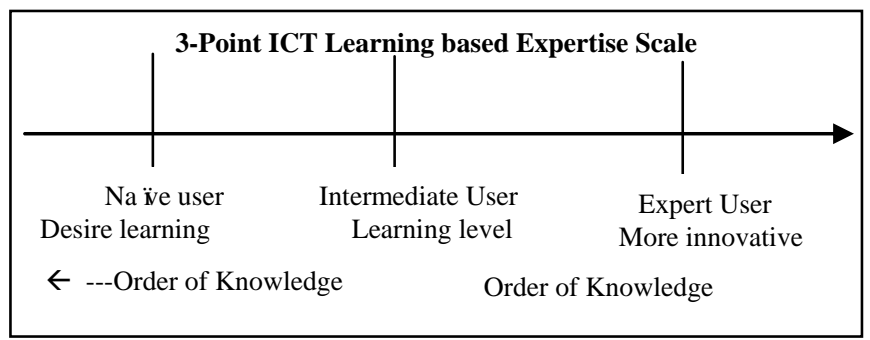

Fig. 4. Three point scale.

\section{RESUlT AND DiSSCUSSION}

Learning is no direct consequence of teaching. Based on this assumption, we have focused on what the students need help to understand, not on the delivery of a number of predefined lectures.Present studies provide glimpse of pedagogical and technological possibilities in the higher education. The new communication technologies are double edged as we are entering a unique and exciting era in digital based teaching and learning. Hence, the technologies invented for human welfare are widening and less ominous. Most respondents agreed that blended learning would have greater significance in higher education in the future. It has greater domain so more higher scope of learning. Although some institutions have already embraced blended learning, many others higher institutions are slower at adopting it for various reasons. Perhaps leadership from the institution is crucial for faculty to obtain adequate support to implement changes in emerging learning and teaching process.

\section{REFERANCES}

[1] P. M. A. Warren, Integrating Technology in Learning \& Teaching, Stylus Publishing Inc., 2000.

[2] Kyong-Jee and C. J. Bonk, The future of online teaching and learning in higher education, The survey Educause Quaterly, 2006.

[3] G. Beauchamp and S. Kennewell, The influence of ICT on the interactivity of teaching, 2008.

[4] D. N. Sansanwal, "Use of ICT in Teaching-Learning \& Evaluation," Educational Lecture series, February 27, 2009.

[5] Anastasia et al., "Applications and Explorations of ICT in Teaching History and Foreign Languages: Students and Teachers Attitude," Perception and Evaluation, Springer publication, pp. 276-281, 2008

[6] R. M. Bottino, The evolution of ICT-based learning environments: which perspectives for the school of the future

[7] J. Fleming and K. Becker "The roles we play in ICT based learning design: Do academics have it all," in Proc. asclite, Singapore, pp 290-299, 2007. 
Boa Reena Tok presently is an assistant professor in Rajiv Gandhi university India, Department of Education Arunachal Pradesh. Coordinator of IGNOU B.Ed and M.Ed Naharlagun. Her main research Education and psychology.

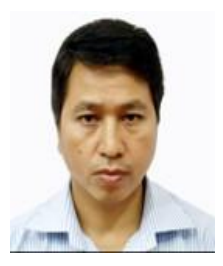

Marpe Sora obtained B.Tech form NERIST and M.Tech from Tezpur University. Presently he is Assistant professor in Rajiv Gandhi university, Department of Computer Science and Engineering Arunachal Pradesh. His main research interests include signal and speech processing, Data mining and HCI. 